\title{
Educational Reform in Ontario: The Importance of Pleasant Avenue School, 1962-1975'
}

\section{Kurt Clausen}

\begin{abstract}
This study examines the history of Pleasant Avenue School in Willowdale, Ontario, during a time when its staff engaged in a significant experiment in curriculum and pedagogical design. As one of the pioneering schools of the Open Concept Plan (and accompanying team-teacher strategies) as early as 1962, it became a model for new school building within the province, and spurred on a number of recommendations made in the influential Hall-Dennis Report of 1968. Through records, interviews, and other primary print/audio visual sources, this study details the school's connection to American counterparts, the factors that led to its immediate success, the influence that it had on the province, and the eventual collapse of the experiment by the end of the decade.
\end{abstract}

\section{RÉSUMÉ}

Cet article analyse l'histoire de la Pleasant Avenue School à Willowdale en Ontario, à l'époque où ses enseignants entreprenaient une expérience d'importance touchant la conception des programmes d'étude et des méthodes pédagogiques. En tant que l'une des écoles pionnières de l'Open Concept Plan (et des stratégies d'enseignement en équipe qui l'accompagnaient), cette expérience est devenue, dès 1962, le modèle pour d'innombrables écoles dans la province et une inspiration pour les recommandations de l'influent rapport Hall-Dennis de 1968. À travers des documents, entretiens et autres sources primaires, cette étude explique en détail les liens entre l'école et ses contreparties américaines, les facteurs qui ont contribué au succès de l'expérience, l'influence de ce succès dans la province et son éventuelle fin abrupte vers la fin des années 1960.

The 1960s has been etched in the popular psyche as an era of protest, dissent and the search for alternatives to mainstream culture, politics and economics of the postwar generation. In the area of education, it has been called a period of revolutionary change whereby outsiders to customary school authority attempted to dramatically overthrow the status quo in order to recreate a radically different system in North America. ${ }^{2}$ However, in recent years, scholarship has pointed out that while this image may have some basis in reality, it would be an oversimplification to dwell on the mere divisions within Canada at this time. Campbell, Clément and Kealey, for example, 
argue that the 1960s should be examined more closely "as a transformative era for Canadian society that was diffuse and widespread." 3 Trends that had begun in the 1950 s, especially in the world of education, were brought to fruition in the next decade leading to significant reforms within the school system. Many of these changes were innovative and influential, but not revolutionary, in that they took place within the public educational system and were strongly supported by educational authorities. Some reforms, too, began merely as practical solutions to perceived educational dilemmas of the 1950s, and only gradually developed into philosophies that diverged from past practice. While some initiatives had a short-term impact, others had a more enduring effect.

Pleasant Avenue Public School, located in the Toronto suburb of Willowdale, is one such example that affords the researcher insight into this period of transformation within the province at a microcosmic level. Constructed in the late 1950s, it became the site of an innovative experiment in "team teaching" and "Open Concept Design" throughout the early 1960s, gaining some recognition from school boards and the Department of Education later in the decade. This article examines the impetus that created this school-based reform, its evolution from inception in 1962 to a fully developed stage in 1966, the specific influences it had on provincial policy, and the fragilities that led to the project's demise by the end of the decade. Specifically, it shows that while many of the philosophical underpinnings of the experiment may appear to be rather radical at the time, they should not necessarily be considered rebellious. While the initial experiment was undertaken by a handful of field practitioners, its accomplishments were attained under the watchful gaze and endorsement of public authorities. As such, this case study shows a picture of communication and acceptance of novel practices from level to level within the Ontario educational system at this time rather than the traditional supposition of radical interlopers versus an intransigent hierarchy.

\section{Learning to Learn}

Between 1966 and 1968, a black-and-white 8mm film circulated throughout the North York Board of Education. Entitled Learning to Learn, it told the tale of an experimental project that was taking place at Pleasant Avenue P.S., one of its elementary schools. Played during professional development day sessions, copies were also made for other boards, teachers' federations and the Department of Education. Within this 17-minute production, set to the evocative strains of Gordon Lightfoot's version of Phil Ochs' "Changes," the disembodied voice of Kenn Johnson (the head of the experiment and principal of Pleasant Avenue) explains the changing and complex world that children must face as they grow up, and the role that the school must now play in order to help them cope with this challenge. In doing so, the film relays four philosophical conclusions reached by this project since it began in 1962. Based on this archival footage, it may explain why, after viewing it, so many within the teaching profession flocked to the Pleasant Avenue Experiment to see if there was truth behind the bold statements found on its celluloid representative. 


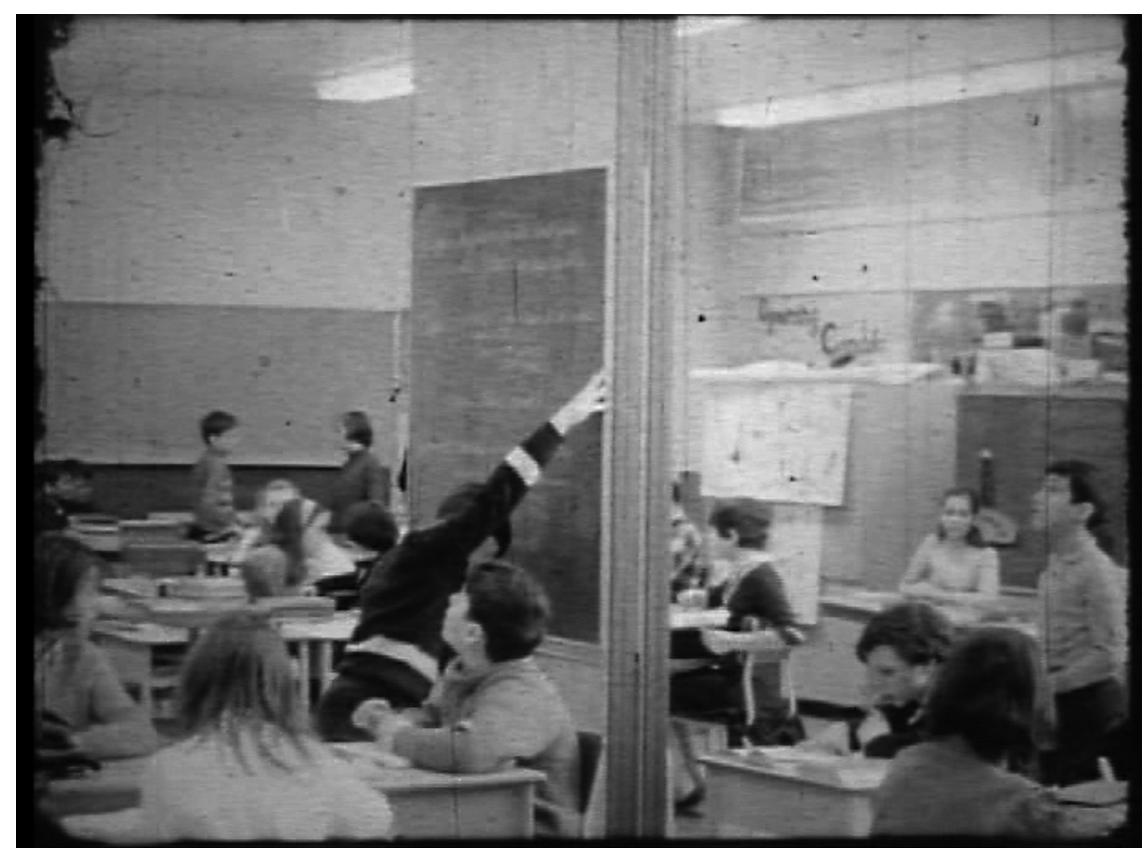

The walls come down between two classrooms, as seen in the film Learning to Learn (1966). Courtesy of Kenn Johnson.

The first and most central conclusion displayed in the film was the need for a shift from a teacher-centred to student-centred vision of education. Kenn explains:

Our teacher is faced with the task of taking this rollicking boy and developing him into a responsible person. His teachers' biggest challenge will be to help him become an independent learner.

In order to achieve this end, the film asserts that teachers must do more than lecture students on becoming responsible; they must incorporate student independence (and, eventually interdependence) into their curriculum. During the school day, students should be able to decide what they are going to learn: this could vary from reading a book, to painting, to building a tower. A more permissive atmosphere is recommended, where students are trusted by the teacher to be responsible for progressing at their own level of achievement.

The project's second conclusion is that the primary tool for student learning is resources, not direct instruction from the teacher. This is reinforced throughout the film with the constant placement of equipment within many camera shots. Film strips, Craig Readers, overhead projectors, records, headsets, and an apparently well-stocked library all attest to the fact that these are readily available. More importantly, the film indicates that the resources are a natural channel for a child's curiosity. It is, therefore, implied that no barrier should be put in the students' way as they do their independent work: 
When he can't find the answer to a problem in his classroom he is free to go to the resource centre where he can seek further information.

The third conclusion of the project indicates that school design must be flexible to meet the changing needs of the students. In one dramatic scene, three students rise from their desks and dismantle a wall, easily sliding it into a closet at the end of a track. To this, Kenn states in enthusiastic tones:

The classroom walls have come down! The senior classroom may be opened up for a large group lesson, for the children learn in groups of different sizes. The two teachers share their resources to make an even more challenging and stimulating program for the children of both classes.

The argument made at this point of the film is that if society would like a child to survive in a changing world, it would be folly to educate them in a static surrounding. Rather, it is explicitly stated that the only way for students to learn to adapt to change is to create a school environment that is constantly changing. Beyond portable walls, the school (as shown in the film) also employs moveable desks of different shapes, mats so students can sit (or lie) on the floor, and equipment that can be easily repositioned depending on the purpose of the exercise.

The final conclusion of the experiment was that a teacher cannot create this type of learning experience in isolation. Instead, the film recommends a "team teaching" atmosphere with a separate room set aside for communal planning. To this end, a number of teachers from the project are shown meeting to discuss common problems, sharing ideas, and introducing new techniques and materials. Kenn argues that as teachers help each other, professional development then becomes a built-in facet of the school, rather than one coming from a higher source (i.e., from the board). There is also the argument that teachers could teach together in one class, or individually take larger numbers of students at one time to free up other teachers for smaller group sessions.

Taken as a whole, this film portrays the Pleasant Avenue experiment as a revolutionary vision for education, juxtaposing it with what it perceived as the more conservative, teacher-centred status quo of Ontario. Of course, almost all of the elements described in this film should not be seen as original, in that they had been promoted in various combinations throughout the province's educational history. James L. Hughes, for example, had been a strong proponent of establishing a child-centred kindergarten programme before the turn-of-the-century, while individual educational scholars and groups all advanced forms of "progressive education" throughout the first half of the twentieth century. ${ }^{5}$ By 1937, even the Ontario Department of Education, through its promotion of a progressively-influenced "Programme of Studies" (colloquially known as the Little Grey Book), anticipated almost all the elements outlined in Learning to Learn. ${ }^{6}$ By the 1960s, some critics were even labeling what they saw as neo-progressivism as merely "warmed over Dewey." This film, by itself, however, gives no indication from where the experiment's philosophy derived, 
or how its educational techniques had evolved and expanded to create the $1966 \mathrm{im}$ age. Is it an accurate representation of what existed at Pleasant Avenue School, or are the images merely idealistic visions of what a school should be, stitched together from past sentiment?

To understand these questions concerning the roots, details and fate of the Pleasant Avenue experiment left unanswered by the film, this study examines the reality of the case by turning to other disparate sources that have luckily remained from this period. Of first importance to guide the study, a number of interviews were conducted with Kenn Johnson (principal from 1959 to 1967), as well as two initial members of the experimental teaching team (Margaret Calver and Sheila Beart). ${ }^{8}$ Kenn, recognizing the importance of this experiment at the time, had also collected a substantial private archive of related documents, consisting of ongoing reports and memos within the North York Board of Education (1961-1967). As it had won some fame at the time, details and conclusions of the project were also recorded in W.S. Fleming's compendium of local projects in his Ontario's Educative Society series.' Finally, the Archives of Ontario (RG-2) contains a tour report that the consequential "Hall-Dennis" Committee created after visiting the school in 1966. From these sources, this study has endeavoured to reconstruct the chronology of this experimental project and its effects on the province. ${ }^{10}$

\section{Arriving at Pleasant Avenue}

Perhaps the origins of the structural and pedagogical transformation of Pleasant Avenue School may best be traced to the personal history of its first principal, Kenn Johnson. After two years' experience in Ottawa, Kenn accepted a principalship in the North York Board of Education in 1957 (at the age of 27). Like many North American urban centres, the area had experienced a great boom in student numbers since the end of the Second World War, and had responded by building everincreasing numbers of larger schools. As the 1950s wore on, this had meant the gradual disappearance of one-room schoolhouses to be replaced with larger amalgamated buildings to house single-grade classrooms. With this had come a concomitant decrease in curricular flexibility on the part of the teacher. Experiments had been undertaken as part of the Porter Plan ${ }^{11}$ starting in 1949 to help teachers develop locally-based courses of study, teams of grassroots planning, and professional development. However, with snowballing student numbers created by the baby boom, and a noticeable teacher shortage, the professional training and qualifications of educators declined. Most shocking was the creation of a truncated certification programme that consisted of a six-week summer course followed later by a full year at teachers' college. The result was a growing teaching population that was young, inexperienced and reluctant to go beyond Departmental directives. ${ }^{12}$

The educational historian, Robert Stamp, concludes that the Minister of Education at this time, W.J. Dunlop, had little alternative when faced with this emergency situation: "he had to provide a teacher for every class-room." ${ }^{13}$ However, in many ways, the pattern of grade levels and subject areas that had been set in most 
urban areas by the twentieth century had led to a rigid compartmentalization of the 1950s school-system. By the time Kenn entered his first school, he felt justified in condemning it as "an egg-crate" consisting of one long hallway with individual classrooms lined up on either side. Here, each room was identical in size, each with the same number of desks (thirty) and equipment tied to each class. In other words, although the school was put together as a community, it was still, in essence, a conglomeration of self-contained "kingdoms" where individual monarchs ruled in "the splendid isolation of the single classroom." 14

By 1959 he was made principal of a K-8 school that was being constructed in the brand new suburbs of Willowdale. Inoffensively titled Pleasant Avenue Public School, it resembled all the other "egg-crate" designs he had experienced. A psychologist from the Forest Hill School Board, talking about teen culture that same year, may well have been discussing the conformity of the schools themselves when he commented: "There are no mavericks left... Everybody wants to be like everybody else." ${ }^{15}$ However, the increasing numbers of students entering the public system during this time had necessitated some innovations in building styles (i.e., portables and larger buildings) simply to deal with the physical strains placed on school structures. In Ontario, Pleasant Avenue was to become a forerunner to these changes, centering on the necessary construction of an additional wing of the building. At this point, buoyed by what he was observing south of the border, Kenn decided to try out a "maverick" idea that he had been mulling over since he left Ottawa. ${ }^{16}$

During his M.Ed. studies, he had examined an experiment that was emerging from Harvard University. The Dean of its Graduate School of Education, Francis Keppel, had challenged his faculty to help revitalize the discipline by defining and implementing new ideas through practical fieldwork. This had included a technique termed "team teaching" which involved teachers sharing classes in different formats. Seeing the potential for a significant increase in professional discussion and interaction, Robert Anderson was one of the first Harvard staff members to take up this directive. In 1957 he helped launch and direct the first team-teaching program in North America at the Franklin Elementary School in Lexington. By the time the North York School Board was contemplating a new wing for Pleasant Avenue School, the results of the Harvard project had been widely studied by intellectual circles across the United States. Anderson wrote extensively on the subject, and, in 1959, published a run-away success with John Goodlad, The Nongraded Elementary School, extolling its virtues when used in conjunction with the practice of "continual progress." By November 1960, Howard K. Smith and a CBS news crew heightened public awareness of this reform by coming to Lexington and filming a documentary on team teaching. ${ }^{17}$

Recognizing the importance and timeliness of this new pedagogical method, Kenn acted swiftly. As the newly-elected president of the North York branch of the Ontario Public School Men Teachers' Federation (OPSMTF), he had been given the duty of finding speakers for their annual meeting. He invited Robert Anderson as the keynote speaker to introduce the crowd to the "cutting edge" experiments from the 
south. From this encounter onward, Kenn set to work on replicating the Lexington experiment in Willowdale, and in so doing, endeavoured to ensure that the new addition to his school (and the accompanying staff) would not fit the "egg-crate" form.

After pondering a number of variations of the Anderson model, Kenn approached the matter with the school's inspector, George Noble. ${ }^{18}$ Initially taken aback by its novelty, Noble advised Kenn to write up a brief which he would send up the administrative ladder. By the spring of 1962, therefore, the proposal "Design for a Research Experiment in Team Teaching” was submitted for board approval. Understanding the radical nature of his experiment, Kenn made certain that it was initially modest in scope, and written in a very scientific manner. In essence, he proposed that three teachers of one grade (who would form the nucleus of the team experiment) be assigned to the school the upcoming September to teach approximately 75 children. ${ }^{19}$ While classroom autonomy would be retained, teachers would learn how to work together as a team over the course of the year to plan and execute the three classes as one programme. He reasoned that the Grade One level would be the most appropriate for this experiment:

Grade 1, I feel, is the ideal grade in which to experiment because the children have come from the freer organization of the Kindergarten and have not been exposed to the lock-step grade structure. ${ }^{20}$

He argued that this experiment would help undermine the conventional notions that all teachers require individual autonomy in their classrooms, that pupils relate best to only one teacher per year, and that the ideal constant class size should be thirty. As well, he hypothesized that an improved pedagogy would be the result (i.e., a more challenging programme, dealing with student needs in a flexible fashion).

Perhaps the most radical aspect of the proposal was that "...class size and bases of group composition would vary from lesson to lesson. The goal is flexible grouping based on specific instructional needs." ${ }^{21}$ He proposed that large group instruction (LGI) would be used during the stimulus phase of instruction (including listening, reading and watching). One teacher could lead the lesson, while the other two could "withdraw the extremes of the grade into interest or ability groups for enrichment activities or tutorial teaching." Once the LGI was complete, teachers could then reconfigure the class into three separate groups for follow-up activities.

The proposal was also spun in such a way as to attract the board's attention to potential savings. It argued that this manner of teaching was a more efficient use of teachers' time and competencies. As well, hints were made that team teaching may be able to handle larger numbers of students than individual methods. Resources could be pooled and used for larger groups, while teachers could capitalize on a quite inexpensive method of professional development, relieving the board of duties that could be downloaded to each school. To further show the frugality of the plan, Kenn requested no additional space for the 1962-3 year, stating that the experiment could take place in 3 standard classrooms, the library, the supply room and the gymnasium, thereby putting minimal strain on the building. He did hint that an extended 
audio-visual centre would be necessary, however. This would house the new equipment that he deemed necessary for the project's success: a tape recorder, film projector, television, a phonograph with headphones for 8 children, 3 filmstrip viewers, and an overhead projector were requested.

After passing a draft of the proposal by Robert Anderson, Kenn finally sent a copy to Noble on March 19, 1962. To his great surprise, it was soon accepted by the board. After some negotiating, Kenn was given control of recruiting new staff members to undertake this project, and a promise that the school would have autonomy and isolation from outside publicity or visitors for two years.

By the late Spring, Kenn began hiring new staff for this experiment. The first of the three new hires was Margaret Calver, who was moving to Ontario after five years' experience teaching primary grades in the Western provinces. The second hire, Sheila Beart, had attended Peterborough Teachers' College, where she was greatly influenced by the progressive master of studies, Phyllis Moore. She taught primary for two years north of Bancroft, and two years in Peterborough, before applying to, and being hired by the North York Board. A third hire, Marilyn Brown-John, had distinguished herself in the primary area of education in Vancouver, B.C. All three new hires were almost the same age with the same number of years' experience. But the more important aspect was that they were all new to the Board from different areas of the country. Kenn bluntly stated that he made it a specific point to avoid taking on local teachers for this experiment: he did not want educators who had become "set in their ways" or had been inculcated into one type of teaching so prevalent within the board. Instead, he recalled, he wanted teachers who had enough experience to be competent, but were "fresh." 22 Once the hiring was done, he did not immediately reveal the plans he had for these teachers, but bided his time until they arrived near the end of the summer.

A few weeks before classes began Kenn called them together and explained the project he had envisioned. After this, he laid the choice at their feet to proceed or not, depending on how confident they felt about the project. At the same time, he confessed to them that he had hired them specifically for this task and felt they could handle it, based on their backgrounds. In this way, these initial three were given an offer they found hard to refuse. When interviewed, however, these original members commented that by moving to the city they had proven themselves to be fairly enterprising in the first place. Sheila commented:

...we all had taken risks in our own personal lives and now we were taking a risk in education. But we were all confident enough that we could do it because that was the kind of people we were. I don't think there was one of us who you would call a shy wallflower.

However, none of the new teachers understood the "team" concept. As Sheila later commented: "We all knew that the North York Board had a reputation for innovation and allowing creativity... but none of us knew what we were getting in for." 


\section{The Transformation}

To an outside observer, the first two months of the 1962-3 school year must have seemed very much like any another in recent memory: each teacher maintained sole responsibility for one class with approximately 30 students in rows, in an egg-crate school. However, the newly constructed team of three teachers and Kenn (who had assumed the role of "project leader") spent this time in what was described in the interim report as "team readiness." To ensure that all the members felt committed to the project from the start, democratic leadership techniques were established with four equal votes. Over the course of the year, this meant that any decisions regarding the teaching program had to be decided by majority vote. ${ }^{23}$ Together, over the course of this period, the group discussed the principles of the team teaching method and goals were set as to what should be accomplished by the end of the year. The year-end report stated that:

This was one of the most important stages of the experiment and deserved all of the two months necessary to instill a climate for change. ${ }^{24}$

Once the experiment began in late October, the team agreed to meet once a week to plan and organize the ensuing weekly programme. To keep the development

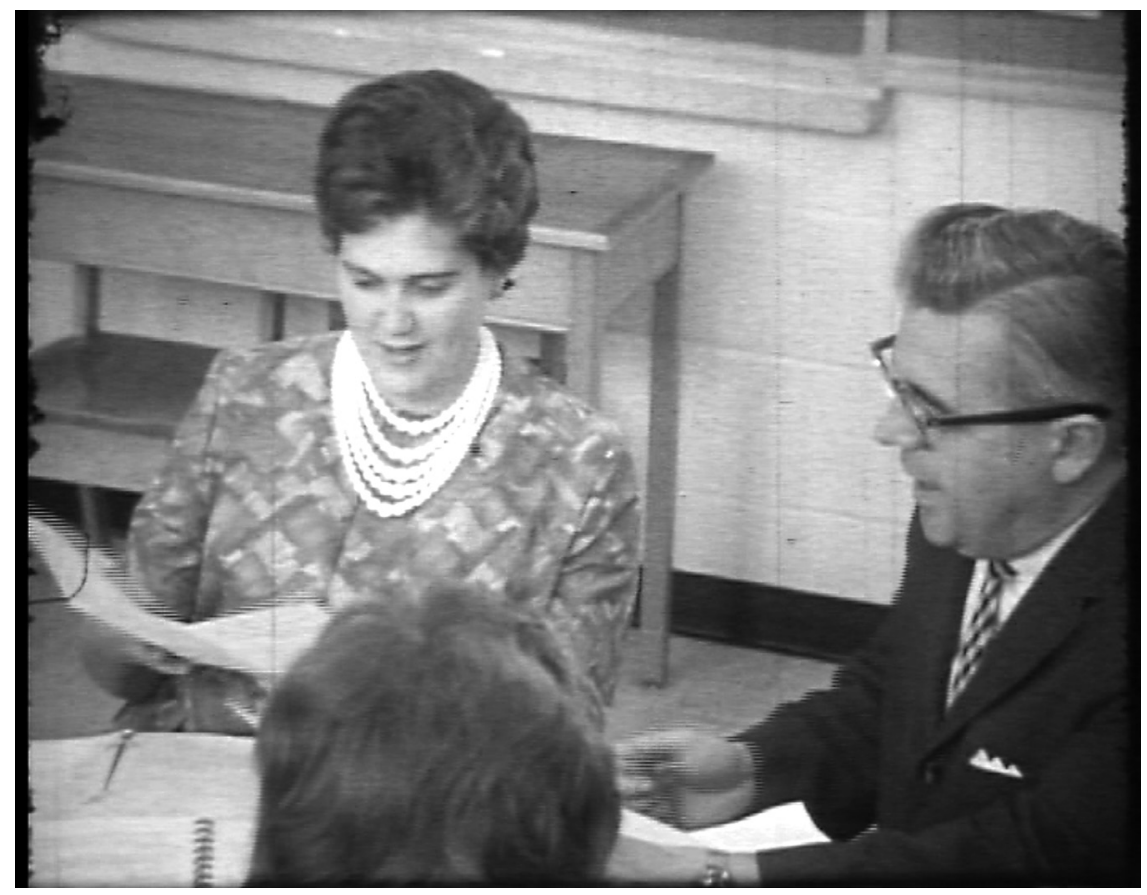

A team meeting in a class-room during the initial phase of the Pleasant Avenue School Experiment, 1964. Visible are Sheila Beart and Kenn Johnson. Courtesy of Kenn Johnson. 
reasonable and controlled, classes throughout November and December followed an extremely mechanistic design and execution with only one 45-minute trial class a day (before lunch or at the end of the day when students were restless). All other periods were conducted in a traditional manner.

After evaluating the students for their progress in language and breaking them into various ability levels, the team proceeded with the pedagogical experiment. At 11:30 am on Thursday, 29 November, for example, the three teachers separated the 80 students into one large and two small Language groups. Marilyn took the large group to discuss beavers and show a story on the opaque projector. At the same time Margaret took the "slow group" to see a film strip entitled "the loose tooth" while Sheila's "fast group" looked at a film strip "Puppy plays a trick." Kenn observed each session, moving from class to class, making notes. Variations on this large/small approach continued for the next six weeks.

Before the end of term, the team met to discuss overall findings of the experiment thus far. They had discovered certain things that they had hypothesized and others that were unexpected: first, they vindicated the times of the day that they had chosen. Through the use of team teaching, what once had been "dead" periods during the day had now become revitalized "with the resultant upgrading of instruction at a time of the day when the pupils are least responsive." 25 This showed that the school day was most effective when based on student interest and physical needs rather than on a linear progression tied to a pre-set curriculum. Accompanying this was the second conclusion: when it came to classroom organization, form had to closely follow function. Specifically, the LGI sessions had shown to be successful if used for specific purposes (like showing a film), while the small group work sessions gave students a closer connection to individual teachers, and a chance to work on isolated skills. In both these cases, the preliminary finding indicated that students were not necessarily attached to one teacher, but showed little tension when switched from one to another.

One of the unexpected results was that the audio-visual equipment, not much utilized in the past, was now being used more frequently, and as a means to an end, not an end in itself.

There is no doubt that the team teaching complex makes better and more efficient use of the school resources, human, mechanical and physical. ... The team of teachers knew little about audio visual instruction at the beginning of the year but now they can handle this teaching aid very effectively. ${ }^{26}$

By the end of April, Kenn attended a meeting of the Special Committee of Written English for the Board. Under its auspices, two other schools, Flemington Park (Junior High) and Earl Haig (Secondary) had been persuaded to try team teaching at their schools. After all three schools reported on their results for the year, the chair of the Committee, Saul Cowan (a trustee), wrote in its report:

The committee was favourably impressed with the results achieved so far... The Committee is of the opinion that these programmes should be continued 
on experimental bases, but should not be extended too materially at the present time. Until the benefits have been determined precisely, the Committee feels that the officials and staff should be reasonably cautious in their approach. They should, however, provide such additional materials, electrical assistance and free time to teachers as necessary to permit the efficient operation of the programmes. $^{27}$

Using the leverage provided by these conclusions, Kenn prepared a year-end report with bolder conclusions and requests than the one prepared earlier in the year. He passed it through the team at a meeting on 16 May1963, and subsequently submitted it to the board. While he argued that the experiment had shown that students were doing no worse than had they been left in an isolated classroom, the real benefits, he claimed, could be found in the transformed role of the teacher.

The teacher is elevated to a higher level of professional teacher than she may have achieved in the past. The team structure makes this type of behavior selfperpetuating. Greater job satisfaction has been noted in spite of increased work load and the strain on an experimental situation. ${ }^{28}$

He further argued that the pupils' positive response to the more resilient and flexible schedule had been greater "than has been imagined in the past." ${ }^{29} \mathrm{He}$ especially praised the use of small-group lessons as a means of drawing out the "slower-learner" (to use the phrasing of the report). Because there were now no feelings of being left behind by the "brighter" ones, these previously reserved students consequently proceeded at their own pace. His final conclusion argued for a change to the status quo:

The sacrosanct postulate that the nearly constant ideal size for a class approximates thirty is left in serious doubt. That teachers rise to a new dimension of instruction that requires professional skills of a high degree has been demonstrated. Whether classroom achievement improves in a similar ratio remains to be proven but such a conclusion in my opinion should follow. ${ }^{30}$

With some confidence, Kenn proposed the expansion of the experiment into Grade 2. Because of the considerably increased workload for teachers doing non-professional jobs (such as arranging chairs, making copies, etc) he also requested a teacher's aide, and a half-day a month for all members to plan as a group. To make this reorganization of classes function effectively, requests were also made for more equipment and especially more space, stating that the vacant classroom they had used the previous year should be maintained and a portable added. Drawing upon teachers' complaints concerning lack of space, he made the broad hint that "when the new addition is added to the school, more suitable team arrangements should be provided." 31 In one final bold request, Kenn recommended that the Grade One team should be funded to: 
visit the school in Cambridge MA where the whole school is operating on a team teaching basis. I feel that such a visit would be invaluable to help the team further refine their skills and insight into the team teaching organization.

In a return letter of June 27, 1963, Superintendent H.R. Partlow gave approval to most requested materials and an aide from "experimental funds." He even allowed the visit to the Lexington School experiment.

By the start of the 1963-4 school year, two teams of 4 teachers each had been set up on separate floors, one to deal with Grade 1s and the other for Grade 2s. A "combined team planning area and workroom" was set aside for each team, where resources were now being stored (previously, each teacher had kept her desk and the material within her own classes). The timetable, although still broken into 45-minute blocks at the beginning of the year, slowly began to mutate as, through communal decision-making, the teams made changes from week to week. With results being returned from ongoing testing, the minutes for the October $30^{\text {th }}$ combined team planning meeting indicate how they began to question past practice:

...Find there is not the same need for seatwork. Maybe a lot of the seatwork in the past has just been busywork while the teacher was dealing with one group. Already the children are well ahead of where they were last year. Teachers are very pleased with the progress. Slower ones in particular are ahead. Children are remembering the projected image of words better.

After this point, there seemed to be a break with the mechanistic approach that had been used during the pilot year:

The three grade one classes are completely integrated for instructional purposes. The entire pupil complement is treated as a unit. Large group, intermediate group and small groups are organized from this pupil base. There is complete flexibility and mobility in the way pupils move to their groups. The groups vary each day according to the needs of the pupils. ${ }^{32}$

By the spring of 1964, work was about to begin on the additional wing to the school, and the staff appeared to have some direct influence on how it should look. In the 2008 interview Kenn sternly commented, "Why should some disconnected architect design the wing, when it was the teachers who were going to use it?" For this reason, Kenn commented on this next hurdle:

...we got a hold of it and designed it and the architects weren't happy, but I [argued that] the function should dictate design... that's the point. And they finally bought that. I had to send a brief to the Department of Education, too. And, they wouldn't believe it when they got it. But finally they approved it. I had a tough time getting it through, but, finally they approved the design. 
As shown by the design written out in pen, a team teaching area was created based on the experiment that was in progress. In the space where 4 standard classrooms should be, there also existed some flexibility to create smaller or larger ones based on the use of partitioning walls. There was also room for a communal, team-planning workroom off the large classroom. Once it was completed, Margaret Calver commented on the expense of the room, noting particularly the large number of cupboards, closets and racks for storage. Rather than the old egg-crate model, Kenn jokingly referred to the whole plan, designed by the team, as "an omelette with sliding doors." ${ }^{3}$

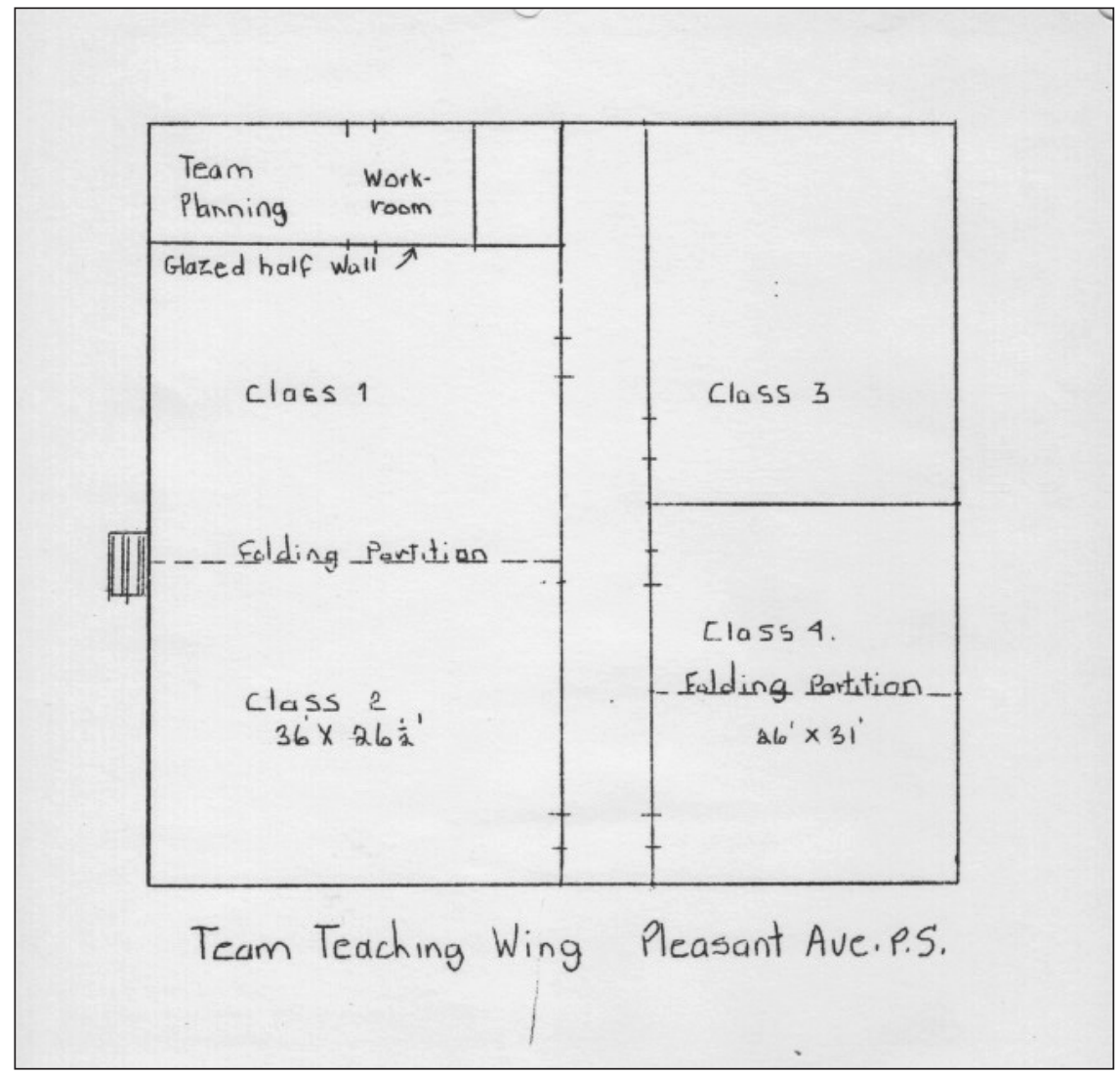

Blueprints developed by the Pleasant Avenue School staff in 1963-4. Courtesy of Kenn Johnson.

With the new wing finished for the 1964-5 year, team teaching seemed to become less of an experiment and more of a common practice throughout the school: alongside the first two grades, Grade 3 (whose students had been the original subjects in the pilot year) and a split Grade 5-6 were also added. ${ }^{34}$ More financial demands were made and met: filmstrip projectors, screens, additional mats, readers, and other resources, secretarial support and half-days reserved each month for team planning. The only request that was questioned concerned return trips to see American 
examples of team teaching. In a back-handed compliment, Partlow responded:

....after a few visits have been made to other centres and we have some experience in the field, I believe our need to visit will be reduced. This is particularly true when it is apparent that our programme is as effective, or more so, than those visited. ${ }^{35}$

Over the course of the year, many of the subject areas began to be integrated on a thematic basis. As well, with more grades involved, teachers began to experiment with cross-grade education (i.e., between Grade 2-3 and 5-6). Based on the testing that was being done, individualized programmes and continuous progress were also being added to the experiment as more effective ways of organizing the school to enrich and enhance the natural way students learn and behave. By the March 17 meeting, discipline and behavior had, in fact, become a central aspect of discussion. Why were students being sent to the office? What could be done to keep students focused? While no answers are given in the notes, the 1966 film provides an explanation:

... there are rules in the school and children will sometimes forget them — being children. The teacher's reaction is to help them develop self-discipline. The teacher strives to prevent problems with boys by keeping them active and interested.

In fact, by this time, there was a marked resemblance between the sentiments found in the school's reports to the board and the film. The 1965-6 year-end report, for example, shows how far the experiment's philosophy had shifted from the mechanistic model that had first been employed:

Rigid scheduling does not meet the needs of primary children in particular. The teachers will team for units and themes that seem to lend themselves to this type of organization. Independent study, the language-experience approach to reading, individualized reading are innovations that have become a vital part of the total school programme. The organization of the school is continuing to move in the direction of an ungraded, self-contained school, with flexible groupings to meet instructional needs.

To this end, the report proposed adding another teacher to Grade One to reduce the teacher-student ratio and add the ability to have more small group or tutorial lessons - a far cry from the initial proposal that propounded efficiency and cost-savings.

\section{Under the Influence}

By the summer of 1964, with most primary-junior grades taking part in the project, and the new wing being built, Kenn shifted his role from "team leader" to school promoter, and used a number of communication outlets to broadcast the experiment's 
findings. The first and most direct way was to send out an announcement to the board signaling the opening of their doors to visitors:

The team would be most pleased to welcome anyone who would like to see our team teaching programme in action. It is the best way to clarify both the theory and practice of the team teaching concept as it has been adapted at Pleasant Avenue School. ${ }^{36}$

Unfortunately, when over a hundred visitors arrived within the first few months, the teams (some in their pilot year) were somewhat unprepared to receive them. As no specific time of the week was earmarked for tours at first, visitations could happen at any moment, and last from a half hour to a few days. By 1965, a hundred and fifty callers arrived from as far away as Vancouver, Edmonton and Montreal. Whole contingencies of inspectors came to fill the classroom as the team tried to carry on. Unfortunately, the teachers found these "performances" stressful, and unexpected visits from dignitaries distracted the students. By the second year, a formal proposal was sent to the Board to limit visitations to one day per month and by 1966, this proved to be a good choice. By 1967 a further recommendation was made to restrict access to the school to only those visitors who would be willing to spend several days with the team. Otherwise, the report concluded, "a casual visitor receives only a cursory impression of the ongoing dynamics involved in a fluid team organization." 37

In collaboration with this approach, by 1965 Kenn began using his connections to the Toronto Teacher's College to maintain a steady stream of student teachers into the school as a base for practice teaching. Deemed an immediate success by the evaluating masters who visited the site, one report observed that "the team offered the students a supporting, secure environment for professional growth and development." ${ }^{38}$ By the end of the year, two student teachers who had proven quite adept at team teaching were hired as replacements for next fall at Pleasant Avenue. This technique was recognized by many principals in the board, who half-jokingly criticized Kenn for cherry-picking the best students as his own personal acolytes. To this, Kenn would simply reply that he had constructed his own mousetrap and that they should go and build their own! ${ }^{39}$

Still strongly connected with the OPSMTF, Kenn became a contributing editor to the federation's main communication organ, The Educational Courier. Over the period 1964 to 1969, Ken contributed no less than a dozen articles, opinion pieces and editorials to the bulletin, many reflecting his school's findings. Two, in particular, outlined the history of the Pleasant Avenue experiment in great detail, the conclusions the teams had found, and caveats to those who wanted to follow its example. ${ }^{40}$ A foreshadowing experience was later relayed by Kenn:

As one well-meaning principal said to me, 'Please write another article for the Courier - I have to know what to do next!' That kind of person should remain in a traditional school. ${ }^{41}$ 
Accompanying his writing, Kenn attended as many meetings as possible of trustees, inspectors and the Ontario Educational Research Council. There, he met and discussed his project with what he described as "key players" at the time.

Finally, two films were created about the school and its teaching techniques as a way to introduce the school to visitors. The first, a choppy 5-minute endeavor was created in 1964 and showed only the mechanistic benefits of the experiment (i.e., the use of various equipment and seating arrangements). However, early reports mentioned that the film had "proven to be very useful when speaking to visitors or parents." ${ }^{42}$ For this reason a second, more elaborate production (Learning to Learn) was created by Kenn and his vice-principal Norm McGurr. As noted above, this caused a greater stir within the board, adding to an even greater increase in visitations.

In undertaking these media campaigns, Kenn had hoped ultimately to create a "laboratory school" that aided educators in their own experiments to create more effective and individualized programmes throughout the province. Eventually, he had hoped to permanently change the "way things were done," and create a new reality for the province. And, until 1967, this technique of promotion proved to be quite successful. After giving a great deal of funding and leeway to this particular site, the board was ready by 1965 to give it "flagship" status, making it one of the obligatory destinations for those visiting the board. In fact, one of Ken's strongest early arguments for reform was now being espoused by the North York Board throughout the province: why go to the expense of sending officials, teachers or consultants on expensive trips to the United States to observe an innovation, when they could see it done just as well in the hinterland of Toronto?

It was perhaps for this reason that the "Provincial Committee on Aims and Objectives of Education in the Schools of Ontario" paid a visit in May 1966. As part of a tour "designed to allow investigation of school organization for instruction," three committee members visited Pleasant Avenue and a few other Ontario schools, as well as the more well-known examples of continuous progress in the United States: Nova Schools, Melbourne High School, and Newtonville, Massachusetts. ${ }^{43}$ Based on these models, the committee found that there was a growing and widespread movement to "individualize" instruction, allowing learners to achieve at their own pace. Specifically, the tour report stated that rather than dealing with each aspect separately, the various elements they witnessed had to be woven together: team teaching, continuous progress, increased use of resources. In the end, the tour group made the following recommendations to the larger committee:

That there should be provision for alternative organization depending upon local needs, for example, continuous progress, team teaching; That there be a basic essential core curriculum for the Province with ample provision for local adaptation and development; That local initiative should be encouraged; That the provision for needed services and equipment can no longer remain an option, such as general purpose room, library, hardware, staff services; That experimental schools be established and maintained... ${ }^{44}$ 
When the committee's final report, Living and Learning (famous by its colloquial name "The Hall-Dennis Report"), was brought before the legislature in 1968, it signaled a sea change in education in the province from a centralized to a de-centralized system. In it, the four elements outlined by Pleasant Avenue School seem to have been taken to heart.

Recommendations were made by the report emphasizing the discovery method, learning experiences that attended to the needs and interests of the student, a curriculum that focused on long-term projects over homework drills, and the abolishment of coercive means of discipline. ${ }^{45}$ As well, resources were recognized as a basic element in all school designs. The report advocated that funds should be allocated to procure them at the school level, staff members should be trained on how to use them, and there should be easy access to them at all times. ${ }^{46}$ And in an uncanny parallel to Pleasant Avenue School's findings, the report recommended that the school system should "provide training for pupils in the use of technological devices which will enable them to make independent use of the great variety of materials and aids now available." 47

Finally, there were a number of recommendations that argued for a flexible school design that had been seen in the Pleasant Avenue experiment. Recommendation 206 states, for example:

Stress the principle of flexibility so that the curriculum embraces a variety of patterns, such as individual study, laboratory and field experiences, large and small group activities, and regular class sessions. ${ }^{48}$

While this had also been observed in some American schools during their visit, the committee specifically noted this in the one Ontario example. To enable this flexibility in curriculum and organizational design, it also recommended that teachers be involved in policy-making and new school planning. ${ }^{49}$ Looking at this experiment and various others throughout the province as success stories, the report finally recommended that select schools should be deemed demonstration schools for those wanting to investigate particular aspects of education (like team teaching). ${ }^{50}$

From this point on, the example set by Pleasant Avenue and other experimental schools observed by the Hall-Dennis Committee began to be seen as de rigeur throughout the province. However, without the creation of a provincial coordinator to facilitate growth, the approach was rather unevenly implemented. Many boards instigated the use of these various techniques in all schools, but frequently through mandate rather than the grassroots training that Pleasant Avenue teachers had received. By the late 1960s, partitioned walls, various classroom sizes and teacher workrooms had become standard features of most new schools being built (albeit with little staff consultation). Some schools went even further than Pleasant Avenue had ever envisioned: rooms open to hallways, or other classrooms, separated only by pillars. William Berczy Public School in Unionville, for example, was built in 1968 with two central hubs connected by the library, with large attached pods, and moveable walls. This open concept plan soon spread to the secondary level with the 
building of Clarkson Secondary School in the Mississauga region (in 1969), followed by the Woodlands Secondary School (in 1970) in the Mississauga region, Overlea Secondary School (in 1972) in Toronto and Bayridge Secondary School in Kingston (in 1974).

By the late 1970s, however, this "team-teaching," "Open Concept" design faced a good deal of criticism from the public. Teachers, parents and the media consistently expressed their concerns about the thin walls and "noise leakage" from other classes. Principals who had only brief training in the benefits of this model found it difficult to inspire teachers when they were unclear of the concept themselves. At the same time, many teachers who had been used to their individual classrooms didn't like or understand why they had to plan and teach "cheek to jowl" with colleagues. Based on this backlash, architects soon began to abandon this model, and staff-members piled up bookshelves to sequester their own classrooms once again. By the mid-1990s, many of the original schools were either gutted or seriously redesigned to recreate the traditional "egg-crate" school. ${ }^{51}$

The fate of the Pleasant Avenue experiment by the late 1960s, in fact, foreshadowed this backsliding trend towards isolated classrooms and solitary teachers. By 1966 , as the school had reached its height of fame, elements began to conspire against the experiment. It was in that year that all three original members of the team had started families and, due to the mores of the time, were forced to resign their positions with little hope of return. In 1967, the experiment was put to a greater test when Kenn was transferred to another school. While he was not enthused about the move, he did admit that as Gulf Stream Public School was the largest in the board, it was a promotion of sorts. ${ }^{52}$ As well, he grudgingly acknowledged that it was perhaps time for some other ambitious principals to take a turn leading the school and the project.

Unfortunately, in a short period of time, it soon became obvious that this was a turning point in the experimental nature of the school. After 1968, all media concerning the school ended, and no written communications remain between the school and the board over this matter (at least, after an archival search, none are apparent). As well, the next generation of teachers, it appeared, was not properly trained for the team approach. The partitions seemed to be used more incidentally rather than as part of an embedded routine. Whatever combination of factors, by 1970, this grand experiment appears to have disappeared from public view, and it can only be assumed that the school quickly recidivated back to its pre-1962 routine.

\section{The Educational Importance of the Study}

A number of points emerge that render this case study important in the history of educational reform in Canada. First, it shows a specific, concrete example of how American pedagogical ideas were transported to Canadian soil. Not just seen in terms of vague similarities, this case demonstrates, in explicit terms, how transference of ideas was made from Lexington to Willowdale to Queen's Park. It also explains, to an extent, how certain individuals were converted to the more progressive philosophy of 
team teaching over a period of time (through direct contact with American reformers and experiencing the experiments first hand). Furthermore, it shows that Pleasant Avenue School would appear to have been one of the earliest Canadian experiments (1962-67) to build upon the original Harvard project (begun in 1957), years before the mainstream considered the "Open Concept" design a viable option. ${ }^{53}$

A second issue emerging from this research concerns how far the use of various media managed to extend the influence of this early experiment. It would appear that the school indeed became noticed by sympathetic board and Department personnel primarily through the principal's promotion, bulletins, speaking engagements, tours and films. In so doing, a case may be made that, with this concrete example within Ontario, the concepts of "team teaching" and "Open Design" became more visible and defendable by proponents who would otherwise have had to rely on mere abstractions and ideals. At the same time, while Kenn's actions may have been viewed by colleagues as rebellious, this grass-roots reform did take place within the confines of the educational system - permitted, sanctioned, funded and copied. As such, this case study shows the many gradations of change that were taking place within the province over the 1960s. While the spectator may initially see the film as an artifact of radical proportions, this experiment cannot be seen as revolutionary nor did its participants share the values of more radical educators in the 1960s, such as contributors to This Magazine is About Schools or participants in Rochdale College. ${ }^{54}$

Finally, this case study highlights the extreme fragility of school-wide experiments of this nature. It indicates that for the "Open Concept" design to prosper, a number of design factors (i.e., team-teaching, inquiry approach, continuous progress) must be in place at the same time. When these factors are absent, this model has a handicap from the outset. As well, the approach cannot be mandated and maintained without understanding. As the Experiment's second report explained:

It is a very human response of the organism after it has been through a period of stress to want to consolidate and stratify its position. It is the leader's responsibility to insure that this period of consolidation does not evolve into a stereotype which is difficult to change. The answer seems to be to retain a measure of flexibility within the organization in order that it would be free to meet changing conditions and better ways to instruct children. If this is not done, the team begins to serve a set model which soon becomes unyielding and inflexible. The organization then begins to serve itself rather than the pupils. ${ }^{55}$

This case study illustrates this point. Even those experiments that have achieved some fame and good reputation are susceptible to failure without a strong, continuing network of advocates who understand and share a philosophy towards this form of education. A lesson as important today as it was in the 1960s. 


\section{Notes}

1 I gratefully acknowledge funding from the Social Sciences and Humanities Research Council of Canada for this project.

2 The term "revolutionary" was consciously employed by many who endeavoured to make sense of educational changes during the 1960s. Using the Oxford English Dictionary's definition as a guide ("involving or causing a complete or dramatic change"), research succeeding this period tended to dwell upon the seemingly abrupt breaks from past educational practice at this time, and the importance of rebellious youth in this change process, especially at the university level. See, for example, Arthur Marwick, The Sixties: Cultural Revolution in Britain, France, Italy, and the United States, c.1958-c.1974 (Oxford: Oxford University Press, 1998); Richard Flacks, Youth and Social Change (Chicago: Markham Publishing Co., 1971); Cyril Levitt, Children of Privilege: Student Revolt in the Sixties: A Study of Student Movements in Canada, the United States, and West Germany (Toronto: University of Toronto Press, 1984).

3 Lara Campbell, Dominique Clément and Greg Kealey, Debating Dissent: Canada and the 1960s (Toronto: University of Toronto Press, 2012), 3.

4 Although the film itself does not indicate a date, memos hint at its creation in the Spring of 1966. This is supported by the fact that Lightfoot's recording of "Changes" appeared in his debut Lightfoot!, released in January of that year on the United Artists label.

5 For a more in-depth overview of the work of the "progressive movement" in Ontario, especially that of groups such as the New Education Fellowship and the Ontario Education Association, see Robert M. Stamp, The Schools of Ontario, 1876-1976 (Toronto: University of Toronto Press, 1982); Edwin C. Guillet, In the Cause of Education: A Centennial History of the Ontario Educational Association, 1861-1960 (Toronto: University of Toronto Press, 1960).

6 Details of the creation and substance of this document may be found in Patrice Milewski, “'The Little Gray Book': Pedagogy, Discourse and Rupture in 1937,” History of Education, 37, 1 (January 2008): 91-111; Lynn Lemisko \& Kurt Clausen, "Connections, Contrarieties, and Convolutions: Comparing Curriculum and Pedagogic Reform in Alberta and Ontario in the Progressive Era (1930-1955), Canadian Journal of Education, 29, 4, (2006): 1097-1126.

7 In discussing the Hall-Dennis movement, some authors were unambiguous in their judgment. See James Daley, Education or Molasses? A Critical Look at the Hall-Dennis Report (Ancaster: Cromlech Press, 1969); Charles Deane Kent, Ryerson Cake with Dewey Icing: Some Reflections on Living and Learning (London: London Public Library and Art Museum, 1969).

8 Interview, Kenn Johnson with author, 18 November 2008, Scarborough; Group Interview, Kenn Johnson, Sheila Beart and Margaret Calver with author, 17 September 2012, Willowdale.

9 W.G. Fleming, Significant Developments on Local Systems (Toronto, University of Toronto Press, 1972), 31-35.

10 The historical research for this project was influenced by Norman Denzin and Yvonna Lincoln (eds), The Sage Handbook of Qualitative Research, $3^{\text {rd }}$ ed. (Thousand Oaks, CA: Sage Publications, 2005).

11 This Departmental initiative (named after Dana Porter, the Minister of Education at the time) endeavoured to de-centralize decision-making through school-based curriculum committees. See Harry Pullen, "A Study of Secondary School Change in Canada with a Special Emphasis on an Ontario Experiment (EdD diss., University of Toronto, 1955).

12 This has been detailed in Robert Gidney, From Hope to Harris: The Reshaping of Ontario Schools (Toronto: University of Toronto Press, 1999). 
13 Stamp, The Schools of Ontario, 199.

14 This regal comment was made in Kenn Johnson, "Team Teaching: Panacea or Menace," no date, p. 1.

15 Cited in Alexander Ross, The Booming Fifties, 1950-1960 (Toronto: Natural Science of Canada, 1977), 40.

16 While principal of Cardinal Heights School in Ottawa (1956-58), Kenn created an enriched program to challenge some of the more advanced students. He refers to an unnamed teacher from New Zealand, whose influence here later helped formulate his program concept for Pleasant Avenue School. Johnson, letter to author, August 26, 2013.

17 Richard Kollen, Lexington: From Liberty's Birthplace to Progressive Suburb (Mount Pleasant, SC: Arcadia Publishing, 2004), p. 142.

18 Noble had been retained by North York Board as an inspector since 1955 and was promoted to Assistant Superintendent of Public Schools in 1964. The Educational Courier, 34, 3 (January-February 1964): 54.

19 The brief's writing style and experimental set-up was reminiscent of the Lexington experiment outlined in Robert H. Anderson, Ellis A. Hagstrom and Wade M.

Robinson, "Team Teaching in an Elementary School," School Review, 68, 1 (Spring 1960): 71-84.

20 Kenn Johnson, "Design for a Research Experiment in Team Teaching," North York Board of Education (1962), 2

21 Ibid., 5.

22 This hiring process and its motivations were explicitly mentioned in both the 2008 and 2012 interviews.

23 While this democratic principle was the theory, Kenn later commented "I don't ever remember being over-ruled by the team! We discussed until there was common ground that was in the best interests of the students." Johnson, letter to author, August 26, 2013.

24 "A Report on A Non-Graded Approach to Team Teaching at Pleasant Avenue School, 1962-63," North York Board of Education (1963), 2.

25 "Interim Report - A Non-Graded Approach to Team Teaching," North York Board of Education (1962), 4.

26 Ibid., 4-5.

27 Saul Cowan, Report No. 2. Special Committee on Written English (North York Board of Education) Meeting held 25 April 1963, Adopted 6 May 1963: 129-130.

28 "Report on a Non-Graded Approach," (1963), 2.

29 Ibid., 5

30 Ibid., 6

31 Ibid., 2. One teacher stated that "if an additional team experiment were initiated next year, it would be almost impossible under present circumstances" (p. 8).

32 "Team Teaching at Pleasant Avenue School," North York School Board (1964), 1.

33 Johnson, letter to author, August 26, 2013.

34 As was the prerogative of any member of the school staff, the Grade 4 teachers opted to remain aside from the project (Interview, 2008).

35 Internal Memo, North York Board of Education, H.R. Partlow to K. Johnson, July 13, 1964.

36 "Report \#2 - Team Teaching Programme at Pleasant Avenue School," North York Board of Education (1964), 1.

37 "Proposal for Team Teaching Programme at Pleasant Avenue School, 1966-1967," North York Board of Education (1966), 2.

38 Ibid.

39 Johnson, interview, 2008. 
40 Kenn Johnson, "We Tried Teaching in our Primary Grades," The Educational Courier, 34, 5 (May-June 1964): 23-27; Kenn Johnson, "Report on the Pleasant Avenue Project," The Educational Courier, 37, 5 (May-June 1967): 35-43.

41 Kenn Johnson, letter to author, nd. [2011].

42 "Proposal for Team Teaching Programme at Pleasant Avenue School, 1965-1966," North York Board of Education (1965), 2.

43 This group consisted of the committee members Roger Ingall and Marcel Parent as well as the Departmental resource person Phyllis Moore (Sheila's master at teacher's college).

44 Provincial Committee on Aims and Objectives on Education, "Tour 6-Organizations" (Archives of Ontario: RG-2), 7.

45 See Provincial Committee on Aims and Objectives on Education, Living and Learning (Toronto: The Queen's Printer for Ontario, 1968), Recommendations 19, 20, 22, 28 and 29 (p. 181-2).

46 Ibid. See Recommendations 44, 45, 67 and 68 (p. 183, 185).

47 Ibid. Recommendation 71 (p. 186).

48 Ibid., p. 198

49 Ibid. See Recommendations 172, 207 and 223 (pp. 195, 198, 200).

50 Ibid. See recommendation 79 (p. 186).

51 For example, when Overlea (now renamed Marc Garneau Collegiate Institute) was renovated in 1998, most open concept elements were removed.

52 Within two years, Kenn had accepted a position within the Department of Education and was posted to Ottawa. Johnson, interview, 2008.

53 It was not until the late 1960s and early 1970s that researchers in North America and abroad began publishing works explicitly using the term. See, for example, R.F. Eberle, "The Open Space School," Clearing House, 44, 1 (1969): 23-28; B. Schlesinger. \& J. Youngston, "The Open Plan School: What's Involved for Teachers and Pupils?" School Program, 39, 10 (1970): 52-53.

54 Launched as an independent alternative magazine in 1966 by a group of self-professed school activists, This Magazine is About Schools took a critical view of the status quo in education, and called for more freedom within the system. It rented space from Co-operative College Residences Inc. in downtown Toronto, which in 1968 spawned Rochdale College, an experiment in student-led alternative education.

55 “Report \#2” (1964), 14. 